\title{
THE IMPACT OF SALT (NaCl) STRESS ON GERMINATION CHARACTERISTICS OF GIBBERELLIC ACID PRETREATED WHEAT (TRITICUM DURUM DESF) SEEDS
}

\author{
ORAL, E. ${ }^{1 *}$ - ALTUNER, F. ${ }^{2}$ - TUNÇTÜRK, R. ${ }^{1}-$ TUNÇTÜRK, M. ${ }^{1}$ \\ ${ }^{I}$ Department of Field Crops, Faculty of Agriculture, Yüzüncü Yıl University, 65080 Van, Turkey \\ ${ }^{2}$ Department of Plant and Animal Production, Gevaş Vocational School of Higher Education, \\ Yüzüncü Yıl University, Gevaş, Van, Turkey \\ *Corresponding author \\ e-mail: eroloral65@gmail.com; phone: +90-546-746-6266
}

(Received 26 $6^{\text {th }}$ Apr 2019; accepted $16^{\text {th }}$ Jul 2019)

\begin{abstract}
This research was conducted to examine the effects of gibberellic acid (GA3), which was treated to wheat (Triticum durum Desf) seeds before germination, on their germination and the seedling growth under saline conditions. Durum wheat Güney Y1ldızı variety, four different GA3 (0 (control), 100, 200 and $300 \mathrm{ppm}$ ), and four different salt (0 (control), $50 \mathrm{mM}, 100 \mathrm{mM}$ and $200 \mathrm{mM} \mathrm{NaCl}$ ) concentrations were used in the research. Germination power, germination ratio (\%), germination index, mean germination time, sensitivity index $(\%)$, radicula length $(\mathrm{cm})$, plumula length $(\mathrm{cm})$, radicula fresh weight $(\mathrm{mg})$, radicula dry weight $(\mathrm{mg})$, plumula fresh weight $(\mathrm{mg})$, and plumula dry weight $(\mathrm{mg})$ were examined. The results indicated that the increasing doses of salt prevented germination and growth parameters of wheat (Triticum durum Desf) seeds. It was observed that the doses of GA3 (Gibberellic acid), which were increased gradually before the doses of salt $(\mathrm{NaCl})$, affected germination and growth positively and significantly. The best results of germination characteristics of wheat seed were obtained from the combination of $300 \mathrm{ppm}$ Gibberellic acid $+0 \mathrm{mM}$ (control) salt.
\end{abstract}

Keywords: wheat, gibberellic acid (GA3), germination, salt stress, salt doses

\section{Introduction}

There are many important factors that restrict the efficiency of agricultural production in the world and in Turkey. The first step to eliminate these factors is planting and germinating the seed under suitable conditions (Y1ldiz et al., 2007). Many vegetative and environmental factors such as seed coat, age, dormancy, temperature, humidity, and light play a role in providing these conditions (Hartmann et al., 1990; De Villiers et al., 1994; Khan and Ungar, 1997). Plants are the most sensitive to environmental factors during germination, emergence, and early seedling periods. All of these environmental factors are called stress factors. The effects of these factors on plants often emerge either one by one or together. Because of that, they are examined as either abiotic or biotic factors based on their sources (Anonymous, 2015). One of the abiotic stress factors that were discussed in this study is salinity (Y1lmaz et al., 2011). Salinity is observed in a great portion of the lands on which irrigated farming is practiced especially thanks to the development of irrigation practices. Approximately one third (950 million ha) of the agricultural lands in the world are estimated to suffer from high salinity (Hasegawa et al., 1986; Özkald1 et al., 2004; Taghipour and Salehi, 2008). In Turkey, the salinity problem exists in about 1.5-2 million hectares of the agricultural lands. Wheat is the most grown product in the regions where irrigated agriculture has been started with the GAP project. Especially the majority of durum wheat production is met from this region. Therefore, increasing salinity and alkalinity 
problems in wheat agriculture must be solved. Seen particularly in the regions where wheat is cultivated, the use of poor drainage and faulty irrigation systems is the most important reason. Alkalinity and salinity problems have emerged in our soils as a result of this faulty practice. Salinity that occurs in soil affects transpiration, respiration, and water intake negatively, and also causes root and stem growth to retard. In consequence, hormonal imbalance, transpiration disorder, and inadequate water and nitrate intake occur (Leopold and Willing, 1984; Dölarslan and Gül, 2012). Another problem is that the toxic effects that occur because of $\mathrm{Na}$ and $\mathrm{Cl}$ ions existing in saline soils cause the loss of ionic equilibrium (Siegel et al., 1980; Flowers and Yeo, 1981; İnal et al., 1995).

For this purpose, these harmful effects on the plants should be detected by conducting research on various plants (Gupta and Srivastava, 1989; Pessarkli et al., 1991; Van Hoorn, 1991). In determining salt resistance, the seeds of the varieties are kept in saline conditions and the effects of these conditions on germination criteria are taken into consideration (Begum et al., 1992). In similar studies, it was stated that plants were the most sensitive during their early germination and seedling periods in terms of salt resistance (Shannon, 1984). Also, the threshold of tolerance to salt in each plant varies by periods (Shannon, 1985). Suitable varieties and practices that will minimize yield losses arising from salinity problem, which restricts productivity in plant cultivation, are needed (Şenay et al., 2005). Salt resistance varies much among the plant species. The most sensitive periods in detecting the salt resistance of species are the germination and the early seedling periods (Van Hoorn et al., 2001). Various research studies that will enable a homogeneous emergence by expediting germination under soil conditions are conducted (Duman and Eşiyok, 1998). For this purpose, different methods such as stratification, hydropriming, acid etching, and hormopriming with growth and development regulators and hormones are applied and these methods are called priming treatments (Ercişli et al., 1999; Yıldız et al., 2017). Among these, hormones and especially GA3 (Gibberellic acid) have been used extensively. Salinity is considered to be one of the environmental stresses that reduce the growth and efficiency of most glycophytic plants worldwide. Induces both osmotic and ionic stresses leading to deterioration of many physiological and biochemical processes including salinity, water relations, ionic homeostasis, gas exchange and mineral nutrition (Parida and Das, 2005) Gibberellins are involved in the stimulation of enzymes involved in seed germination. Gibberellic acid (GA3) is one of the hormones proposed to control primary dormancy by inducing germination. Cavusoglu et al. (2007) reported that GA3 was the most effective salt stress reducing agent among plant growth regulators used in the research.

The aim of this study was to reduce the negative effects of salt in saline soils by treating GA3 (Gibberellic acid) on durum wheat seeds (Zheng et al., 2009; Kayış, 2014).

\section{Materials and methods}

In order to evaluate the effect of seed priming on the germination and seedlings' growth traits of Triticum durum Desf. under different salinity stress levels, a factorial experiment was conducted in completely randomized design (CRD) with four replications, at the laboratory of Seed Science and Techonology in the Department of Field Crops, Faculty of Agriculture, Van Yuzuncu Yil University, Turkey in 2019. In the research, Güney Y1ldızı variety of durum wheat (Triticum durum Desf.) was 
provided from GAP Agricultural Research Institute. Wheat is the most grown product in the regions where irrigated agriculture has been started with the GAP project. Especially the majority of durum wheat production is met from this region. Therefore, increasing salinity and alkalinity problems in wheat agriculture must be solved. The Güney Yildizı durum wheat cultivar developed by the Diyarbakır Agricultural Research Institute is a high yield genotype grown in large quantities in the region. The yield of other varieties in saline soils is low compared to this variety. For this reason, Güney Y1ldizı variety was preferred in the study.

Four different GA3 $(0,100,200$, and $300 \mathrm{ppm})$ and four different salt concentrations $(0,50,100$, and $200 \mathrm{mM} \mathrm{NaCl})$ were used in the research. Wheat seeds were surfacesterilized for $5 \mathrm{~min}$ using $2.5 \%$ (v/v) sodium hypochlorite, were washed with pure water 7 times, and were left for drying in a sterile container (Azizi et al., 2011). In the experiment, durum wheat seeds were kept under dark conditions at $20 \pm 1{ }^{\circ} \mathrm{C}$ in three different doses of GA3 (100, 200, and $300 \mathrm{ppm})$ and distilled water $\left(\mathrm{H}_{2} \mathrm{O}\right)$ for $24 \mathrm{~h}$ until the humidity of the seeds became $12-13 \%$. After the waiting period, the seeds were drained; two folds of blotting papers were placed; and the seeds were placed into $9-\mathrm{cm}-$ diameter sterile petris, putting 20 seeds in each petri. Then, $5 \mathrm{ml}$ from the prepared $\mathrm{NaCl}$ solutions at different doses $(50,100,200$, and $300 \mathrm{mM})$ and pure water were applied to meet the water demand of the seeds in the petri that was used for control. After these applications, the seeds in the petris were placed into incubators under $20 \pm 1{ }^{\circ} \mathrm{C}$ temperature for germination and emergence test. The initial tests of the seeds were identified according to ISTA (1996) rules. For the tests applied during germination, the seeds were placed between the two-fold blotting papers, $4 \times 20$ seeds (Photo 1) were used for the tests and the tests lasted for 14 days (ISTA, 1996).

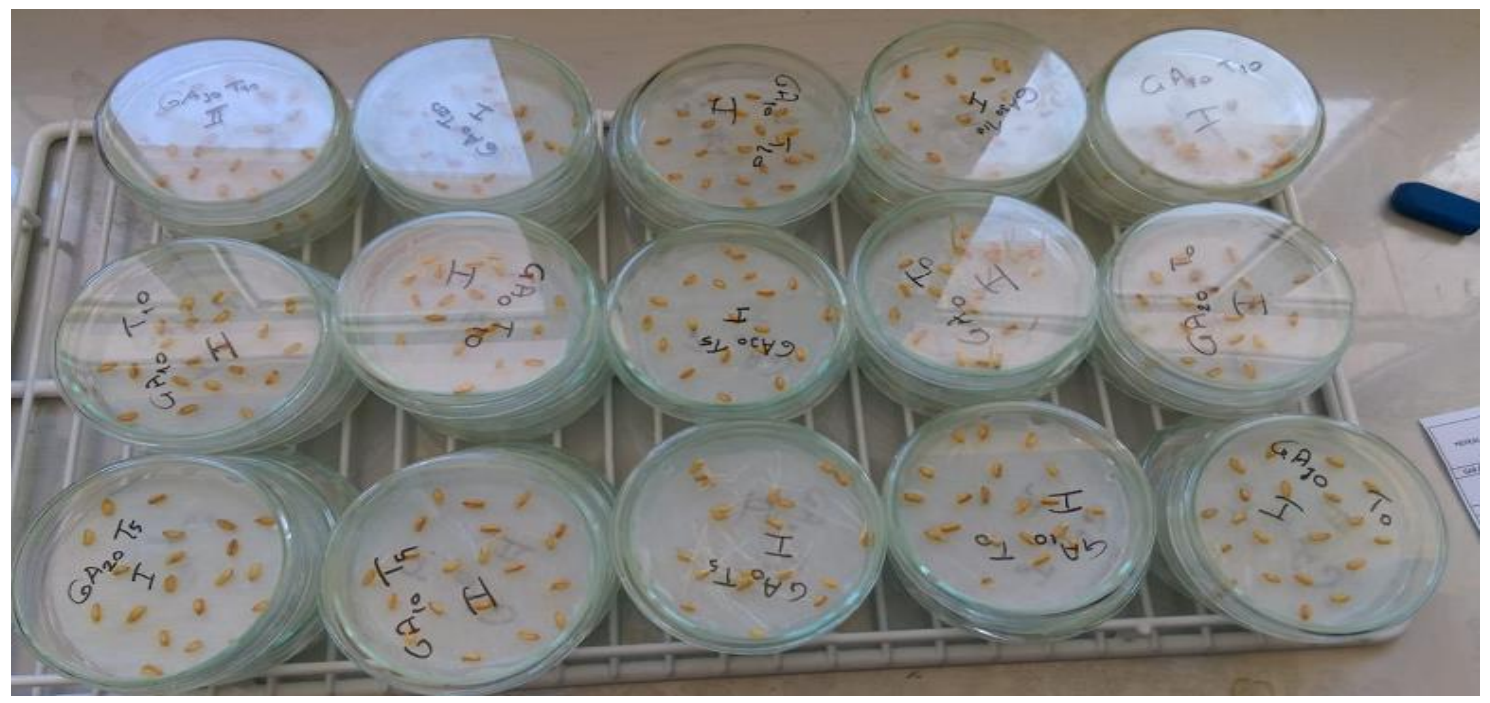

Photo 1. Seeds in petri dishes

In this study: germination power, germination ratio $(\%)$, germination index, mean germination time, sensitivity index $(\%)$, radicula length $(\mathrm{cm})$, plumula length $(\mathrm{cm})$, radicula fresh weight $(\mathrm{mg})$, radicula dry weight $(\mathrm{mg})$, plumula fresh weight $(\mathrm{mg})$, and plumula dry weight $(\mathrm{mg})$ were examined.

Accordingly: root and shoot dry masses were weighed germination rate, germination power, germination index, mean germination time and sensitivity index were calculated 
with the following formulas. It was considered that number of germinated seeds on 7 th day as "germination rate" and number of germinated seeds on 14th day as "germination power".

Germination rate (GR) was calculated using Equation 1 (Akıncı and Calıskan, 2010).

GR = Total seeds germinated after day 14 / Total number of planted seeds (Eq.1)

Germination index (GI) was calculated using Equation 2 (Wang et al., 2004).

$$
\mathrm{GI}=\Sigma(\mathrm{Gi} / \mathrm{Tt})
$$

GI: Germination index; Gi: i days germinated seed rate; Tt: count day.

Mean germination time (MGT) was calculated using Equation 3 (Ellis and Roberts, 1980).

$$
\mathrm{MGT}=\Sigma(\mathrm{fx}) / \Sigma \mathrm{f}
$$

f: Number of seeds germinated $x$ : germination day.

Sensitivity index (SI) was calculated using Equation 4 (Foolad and Lin, 1997).

$$
\text { SI }=\text { MGT in the salt application / MGT in the control application }
$$

Statistical analyses of the obtained data were done using COSTAT (version 6.3) software, and multiple comparison tests of the data were performed according to the Duncan test (Duzgunes et al., 1987).

\section{Results}

According to the results obtained from the research, the effect of salt $(\mathrm{NaCl})$ stress on germination characteristics of GA3 pretreated wheat (Triticum durum Desf) seed was found to be statistically significant. In addition, salt doses $\times$ GA3 interactions were found to be significant in all parameters $(\mathrm{P}<0.01)$ (Tables 1 and 2$)$.

According to the results, the highest germination power and ratio $(93.89 \%$ and $39.33 \%$, respectively) were obtained from $0 \mathrm{mM}$ and $\mathrm{NaCl}$ application; and the lowest values $(61.65 \%$ and 11.78 , respectively) were obtained from the $200 \mathrm{mM}$ salt $(\mathrm{NaCl})$ concentration (Table 1; Figs. 1 and 2). The effects of gibberellic acid on germination power and ratio were also found to be significant; and the highest germination power and ratio were obtained from the 200 ppm GA3 application with $81.39 \%$ and $32.59 \%$. But it is determined that not found significant differences as statistically between 200 and 300 ppm GA3 applications. The lowest values observed as $(75.05 \%$ and $14.01 \%)$ from $0 \mathrm{ppm}$ (control) applications. But it is in the same Duncan groups with $300 \mathrm{ppm}$ GA3 dose application. The salt $\times$ GA3 interactions over the wheat seeds were also found to be significant, and the highest germination power and ratio were obtained from the 300 ppm GA3 concentration $(98.00 \%, 58.33 \%)$ of the control application $(0 \mathrm{mM})$. But, there are not different statistically among all GA3 applications for germination power whereas the lowest germination power (56.33\%) was detected in the $100 \mathrm{ppm}$ GA3 application of the $200 \mathrm{mM}$ salt concentration. 
Table 1. The effect of salt stress on the germination characteristics in the Gibberellic acid treated wheat (T. durum Desf) seeds

\begin{tabular}{|c|c|c|c|c|c|c|}
\hline \multicolumn{2}{|c|}{ Stress applications } & \multirow{2}{*}{$\begin{array}{c}\text { Germination } \\
\text { power }(\%)\end{array}$} & \multirow{2}{*}{$\begin{array}{c}\text { Germination } \\
\text { ratio }(\%)\end{array}$} & \multirow{2}{*}{$\begin{array}{c}\text { Mean } \\
\text { germination } \\
\text { time (day) }\end{array}$} & \multirow{2}{*}{$\begin{array}{c}\text { Germination } \\
\text { index }(\%)\end{array}$} & \multirow{2}{*}{$\begin{array}{l}\text { Sensitivity } \\
\text { index }(\%)\end{array}$} \\
\hline Salt doses & GA3 & & & & & \\
\hline \multirow{4}{*}{ Control (T0) } & GA0 & $90.00 \mathrm{a}$ & $25.30 \mathrm{c}$ & $3.67 \mathrm{c}$ & $13.41 \mathrm{a}$ & - \\
\hline & GA100 & $92.36 \mathrm{a}$ & $33.25 \mathrm{bc}$ & $3.83 \mathrm{bc}$ & $12.56 \mathrm{a}$ & $0.28 \mathrm{e}$ \\
\hline & GA200 & $93.22 \mathrm{a}$ & $40.25 \mathrm{~b}$ & $2.68 \mathrm{~d}$ & $11.25 \mathrm{ab}$ & $0.72 \mathrm{bc}$ \\
\hline & GA300 & $98.00 \mathrm{a}$ & $58.33 \mathrm{a}$ & $0.92 \mathrm{f}$ & $10.65 \mathrm{c}$ & $1.04 \mathrm{ab}$ \\
\hline T0 mean & & $93.39 \mathrm{~A}$ & $39.33 \mathrm{~A}$ & $2.70 \mathrm{D}$ & $11.96 \mathrm{~A}$ & $0.68 \mathrm{~B}$ \\
\hline \multirow{4}{*}{$50 \mathrm{mM}(\mathrm{T} 50)$} & GA0 & $85.32 \mathrm{~b}$ & $15.50 \mathrm{e}$ & $3.90 \mathrm{a}$ & $12.27 \mathrm{a}$ & $0.38 \mathrm{~d}$ \\
\hline & GA100 & $85.36 \mathrm{~b}$ & $20.30 \mathrm{~d}$ & $4.10 \mathrm{~b}$ & $13.34 \mathrm{a}$ & $0.72 \mathrm{bc}$ \\
\hline & GA200 & $85.67 \mathrm{~b}$ & $40.33 \mathrm{~b}$ & $3.32 \mathrm{~cd}$ & $10.95 \mathrm{bc}$ & $1.06 \mathrm{ab}$ \\
\hline & GA300 & $88.36 \mathrm{ab}$ & $49.25 \mathrm{ab}$ & $2.30 \mathrm{de}$ & $11.05 \mathrm{~b}$ & $1.12 \mathrm{ab}$ \\
\hline T50 mean & & $86.17 \mathrm{~B}$ & $32.10 \mathrm{~B}$ & $3.40 \mathrm{~B}$ & $11.90 \mathrm{~B}$ & $0.74 \mathrm{~B}$ \\
\hline \multirow{4}{*}{$100 \mathrm{mM}$ (T100) } & GA0 & $66.70 \mathrm{c}$ & $9.46 \mathrm{~g}$ & $4.15 \mathrm{ab}$ & $10.36 \mathrm{c}$ & $0.55 \mathrm{c}$ \\
\hline & GA100 & $75.00 \mathrm{bc}$ & $27.70 \mathrm{~cd}$ & $2.92 \mathrm{~d}$ & $9.57 \mathrm{~cd}$ & $0.57 \mathrm{c}$ \\
\hline & GA200 & $76.67 \mathrm{bc}$ & $35.45 \mathrm{bc}$ & $2.67 \mathrm{~d}$ & $8.78 \mathrm{~d}$ & $0.89 \mathrm{~b}$ \\
\hline & GA300 & $71.70 \mathrm{c}$ & $11.70 \mathrm{de}$ & $2.20 \mathrm{e}$ & $7.95 \mathrm{de}$ & $1.46 \mathrm{a}$ \\
\hline T100 mean & & $72.51 \mathrm{C}$ & $21.07 \mathrm{C}$ & $2.98 \mathrm{C}$ & $9.16 \mathrm{C}$ & $0.86 \mathrm{~A}$ \\
\hline \multirow{4}{*}{$200 \mathrm{mM}$ (T200) } & GA0 & $60.00 \mathrm{~d}$ & $5.75 \mathrm{~g}$ & $6.33 \mathrm{a}$ & $5.61 \mathrm{e}$ & $0.34 \mathrm{~d}$ \\
\hline & GA100 & $56.33 \mathrm{de}$ & $10.68 \mathrm{de}$ & $3.42 \mathrm{c}$ & 4.69 ef & $0.45 \mathrm{~cd}$ \\
\hline & GA200 & $70.00 \mathrm{c}$ & $14.36 \mathrm{ef}$ & $4.12 \mathrm{ab}$ & $4.35 \mathrm{f}$ & $1.24 \mathrm{~b}$ \\
\hline & GA300 & $60.30 \mathrm{~d}$ & $16.45 \mathrm{e}$ & $5.25 \mathrm{a}$ & $3.97 \mathrm{~g}$ & $1.33 \mathrm{a}$ \\
\hline T200 mean & & $61.65 \mathrm{D}$ & $11.78 \mathrm{D}$ & $4.78 \mathrm{~A}$ & $4.65 \mathrm{D}$ & $0.84 \mathrm{~A}$ \\
\hline \multirow{4}{*}{$\begin{array}{c}\text { Mean } \mathrm{GA}_{3} \\
\text { doses }\end{array}$} & GA0 & $75.05 \mathrm{C}$ & $14.01 \mathrm{C}$ & $4.51 \mathrm{~A}$ & $8.04 \mathrm{D}$ & $0.31 \mathrm{D}$ \\
\hline & GA100 & $77.26 \mathrm{~B}$ & $22.98 \mathrm{~B}$ & $3.56 \mathrm{~B}$ & $10.04 \mathrm{~B}$ & $0.50 \mathrm{C}$ \\
\hline & GA200 & $81.39 \mathrm{~A}$ & $32.59 \mathrm{~A}$ & $2.26 \mathrm{C}$ & $8.83 \mathrm{C}$ & $0.97 \mathrm{~B}$ \\
\hline & GA300 & $80.14 \mathrm{~A}$ & $31.93 \mathrm{~A}$ & $2.66 \mathrm{C}$ & $10.41 \mathrm{~A}$ & $1.23 \mathrm{~A}$ \\
\hline $\mathrm{CV}(\%)$ & & 8.6 & 17.5 & 13.3 & 10.8 & 11.2 \\
\hline
\end{tabular}

GA0: control doses, GA100: 100 ppmdoses, GA200: 200 ppm doses, GA300: 300 ppm doses, T0: control doses, T50: $50 \mathrm{mM}$ salt doses, T100: $100 \mathrm{mM}$ salt doses, T200: $200 \mathrm{mM}$ salt doses

*The difference between the means was evaluated at $\mathrm{P}<0.05$ and $\mathrm{P}<0.01$ level with the Duncan multiple comparison method

The results showed that the difference between salt, GA3, and their interaction regarding the mean germination time was significant $(\mathrm{P}<0.01)$ (Table 1). The lowest mean germination time (2.70 days) was obtained from the control application $(0 \mathrm{mM})$ of the salt concentration and the longest time (4.78 days) was obtained from the $200 \mathrm{mM}$ application (Fig. 3). Also, the effect of gibberellic acid on the mean germination time was significant, and the shortest time was obtained from the $300 \mathrm{ppm}$ application (2.66 days), and the longest time (4.51 days) was obtained from the control application at 0 ppm dose. In terms of salt $\times$ GA3 interactions, the shortest time (0.92 days) was obtained from the control application $(0 \mathrm{ppm}, 0 \mathrm{mM})$, and the longest time was obtained from the $200 \mathrm{mM}$ salt concentration with the 0 ppm GA3 dose (6.33 days). 


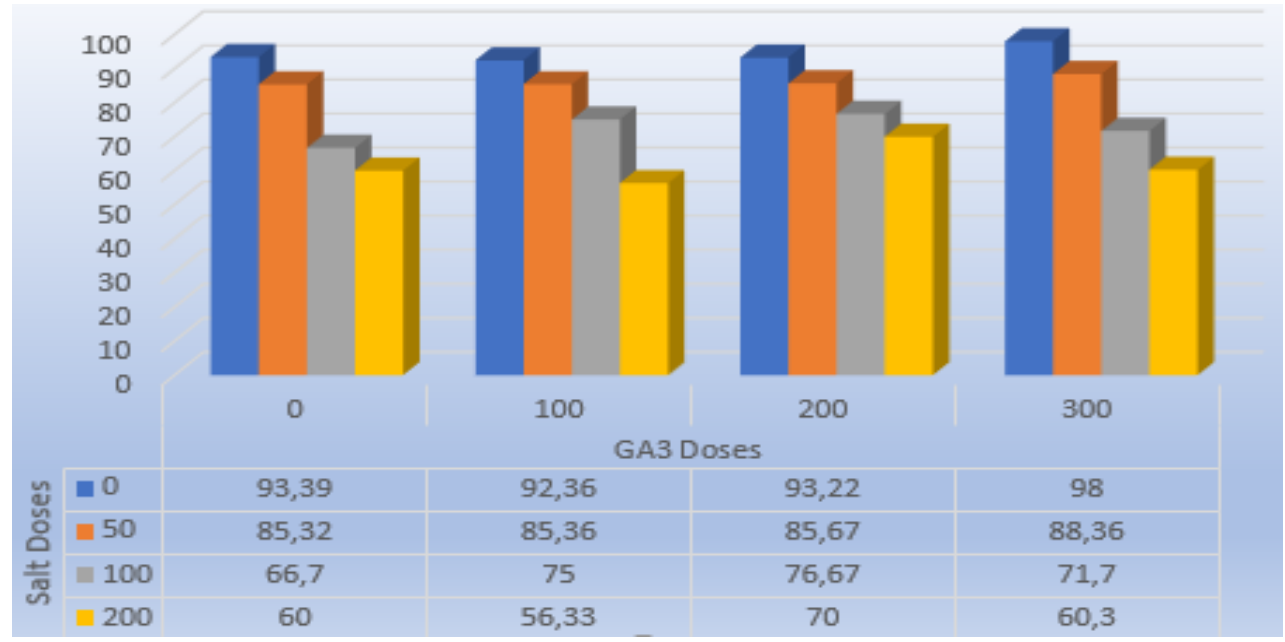

Figure 1. The impact of salt $\times$ GA3 interactions on the germination power (\%)

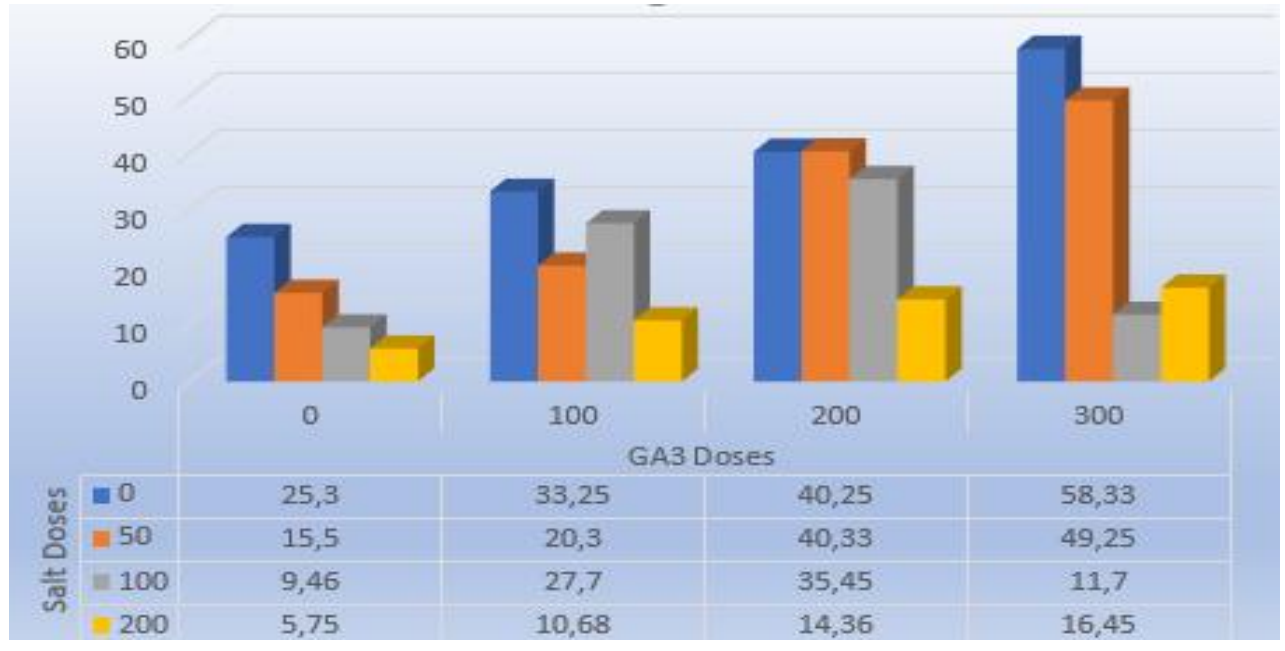

Figure 2. The impact of salt $\times$ GA3 interactions on the germination ratio (\%)

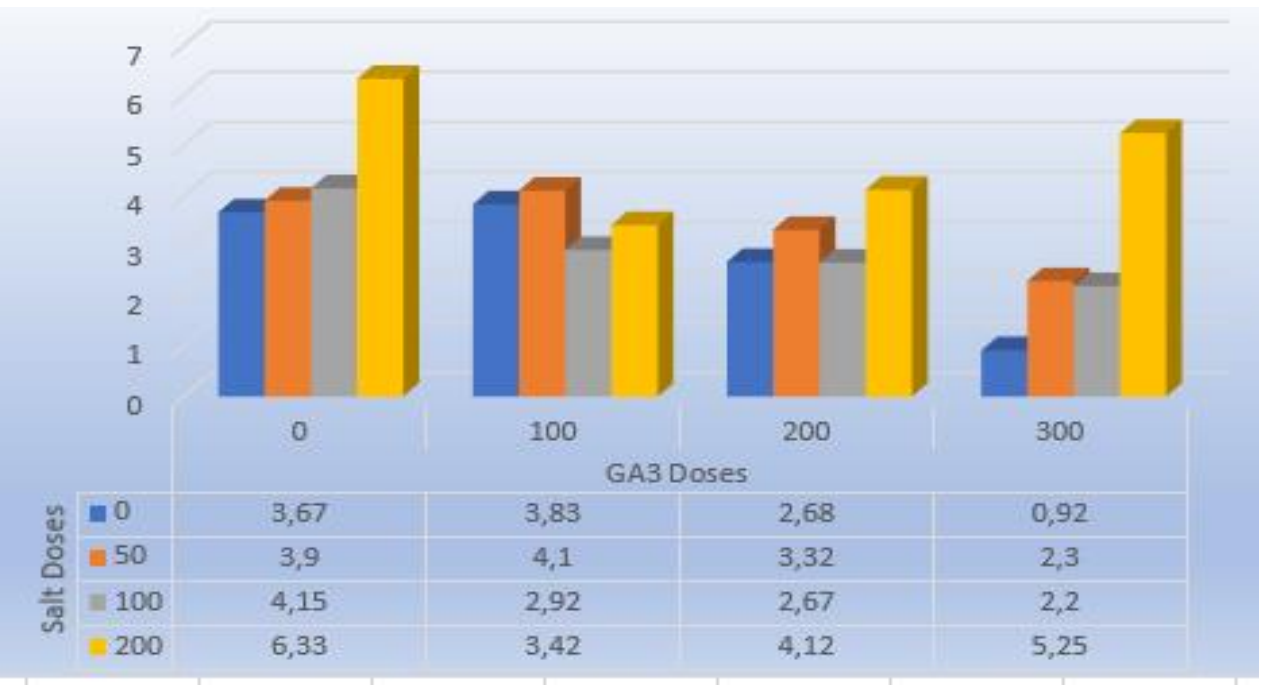

Figure 3. The impact of salt $\times$ GA3 interactions on the mean germination time (days) 
When the germination index $(\%)$ values of the wheat seeds were examined, it was observed that the difference between salt, GA3, and their interactions was significant (Table 1; Fig. 4). The highest germination index between the salt doses was obtained from the $0 \mathrm{mM}$ control with $11.96 \%$, and the lowest index value was obtained from the $200 \mathrm{mM}$ concentration (4.65\%). Regarding the germination index values of the gibberellic acid doses, the highest index value was obtained from the $300 \mathrm{ppm}$ dose $(10.41 \%)$, and the lowest value was obtained from the control. The highest value of the germination index of the wheat seeds obtained from the salt $\times$ GA3 interaction was in $0 \mathrm{mM}$ and $0 \mathrm{ppm}$ GA3 with $13.41 \%$. There is not difference statistically among 100 and 200 ppm GA3 in the 0 and $50 \mathrm{mM}$ of salt applications. The lowest value (3.97\%) was obtained from the $200 \mathrm{mM}$ salt and 300 ppm GA3 applications.

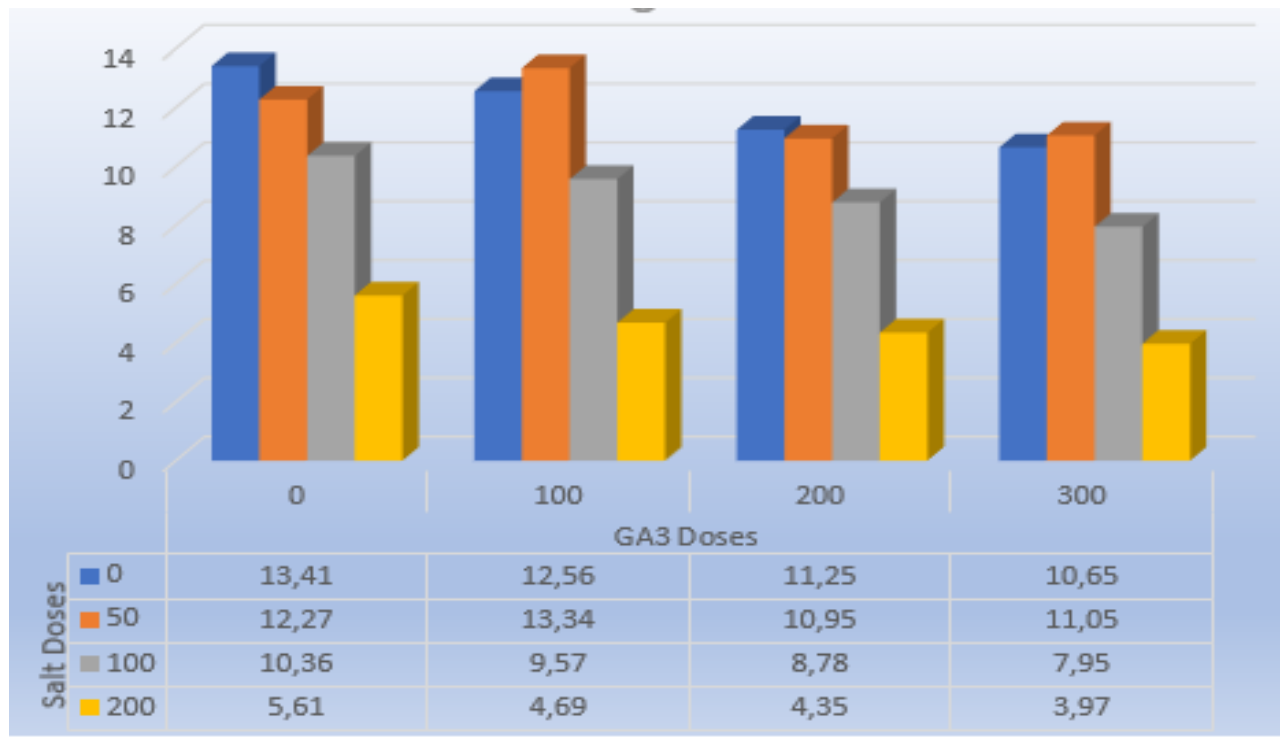

Figure 4. The impact of salt $\times$ GA3 interactions on the germination index (\%)

According to the obtained results, the applications and their interactions were found to be significant regarding the sensitivity index values of the wheat seeds (Table 1, Fig. 5). It was observed that increasing salt concentrations decreased the sensitivity index values. The highest sensitivity index value was observed in the $100 \mathrm{~nm}$ application (0.84\%). But, it is in the same Duncan group with $200 \mathrm{mM}$ salt application. The lowest sensitivity index value was obtained from the control application $(0.46 \%)$ it is in the same Duncan group with $50 \mathrm{mM}$ salt application. The highest sensitivity index values of the wheat seeds to the gibberellic acid doses were obtained from the $200 \mathrm{ppm}$ concentration $(1.23 \%$ ), and the lowest value was obtained from the $0 \mathrm{ppm}$ concentration $(0.31 \%)$. The highest sensitivity index in the salt $\times$ GA3 interaction was found to be $1.46 \%(100 \mathrm{mM}$ salt $\times 300 \mathrm{ppm}$ GA3 $)$, and the lowest was found to be $0.28 \%(0 \mathrm{Mm}$ $\mathrm{NaCl} \times 100$ ppm GA3).

Radicula length values were found to be significant in the wheat seeds in terms of the applications and their interactions (Table 2; Fig. 6). The lowest radicula length was found to be $1.50 \mathrm{~cm}$ in the $200 \mathrm{mM}$ salt concentration, and the highest radicula length $(4.5 \mathrm{~cm})$ was obtained from the $50 \mathrm{mM} \mathrm{NaCl}$ application In the gibberellic acid applications, the longest root was obtained from the $300 \mathrm{ppm}$ dose $(5.54 \mathrm{~cm})$, and the lowest value $(1.21 \mathrm{~cm})$ was obtained from the $100 \mathrm{ppm}$ dose. In the salt $\times$ GA3 
interaction, the highest radicula length was $5.64 \mathrm{~cm}(0 \mathrm{mM} \times 300 \mathrm{ppm}$ GA3 $)$. It is in same Duncan with $0 \mathrm{mM} \mathrm{NaCl}$ and $300 \mathrm{ppm}$ GA3. The lowest radicula length was found to be $0.19 \mathrm{~cm}(50 \mathrm{mM} \times 100 \mathrm{ppm})$.

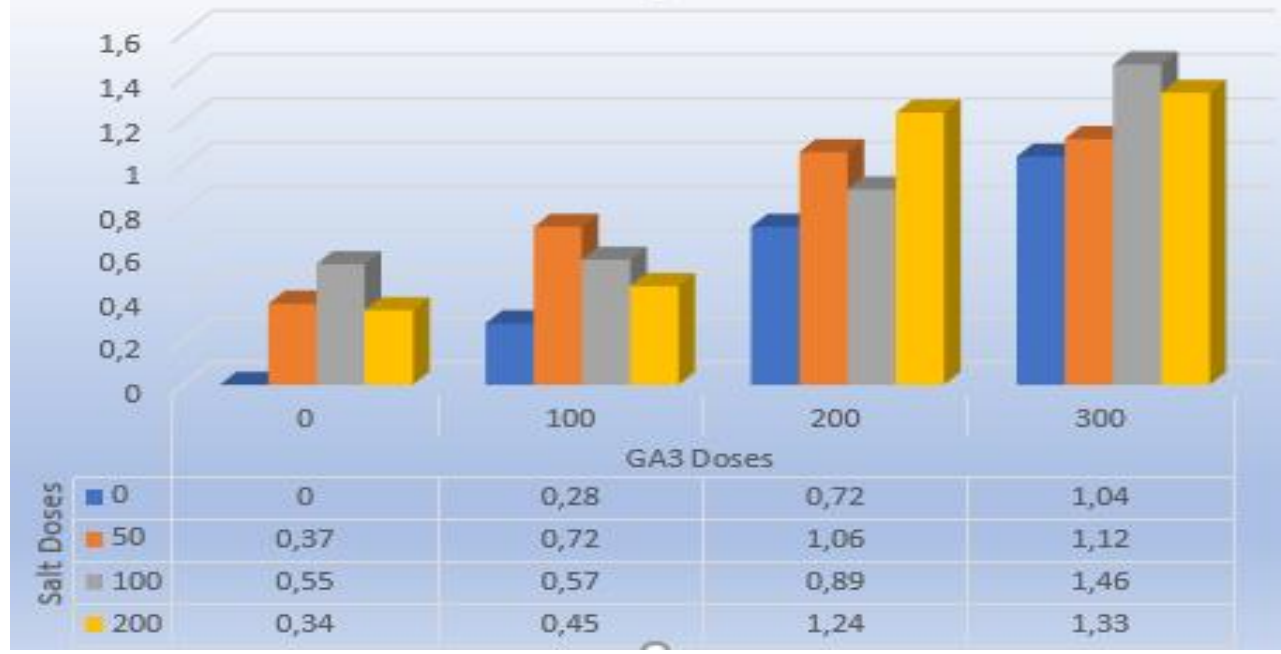

Figure 5. The impact of salt $\times$ GA3 interactions on the sensitivity index (\%)

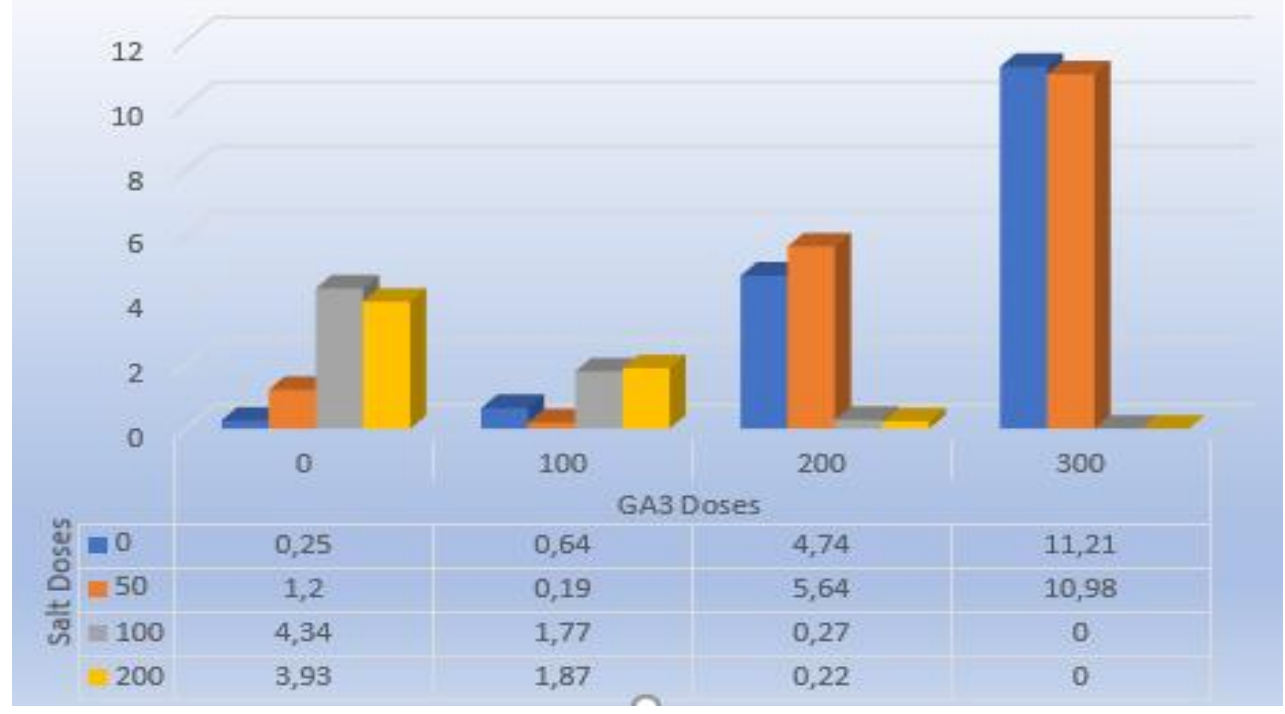

Figure 6. The impact of salt $\times$ GA3 interactions on the radicula lenght $(\mathrm{cm})$

According to the results, the effects of the applications on plumula length were found to be significant (Table 2; Fig. 7). Depending on the salt concentrations, the highest plumula length $(7.29 \mathrm{~cm})$ was observed in the $50 \mathrm{Mm} \mathrm{NaCL}$ dose. It is in the same with control. The shortest stem length was observed to be $2.91 \mathrm{~cm}\left(\mathrm{~T}_{200}\right)$. Despite this suppressive characteristic of salt, it was observed that the gibberellic acid doses increased the plumula length. The highest stem length $(6.20 \mathrm{~cm})$ was obtained from the GA100 dose, and the lowest was $4.86 \mathrm{~cm}\left(\mathrm{GA}_{0}\right)$. In the salt $\times$ GA3 interaction, the highest plumula length $(11.50 \mathrm{~cm})$ was obtained from the $\mathrm{T}_{50} \times \mathrm{GA}_{100}$ application, and the lowest value was observed to be $1.50 \mathrm{~cm}\left(\mathrm{~T}_{100} \times \mathrm{GA}_{300}\right)$. 


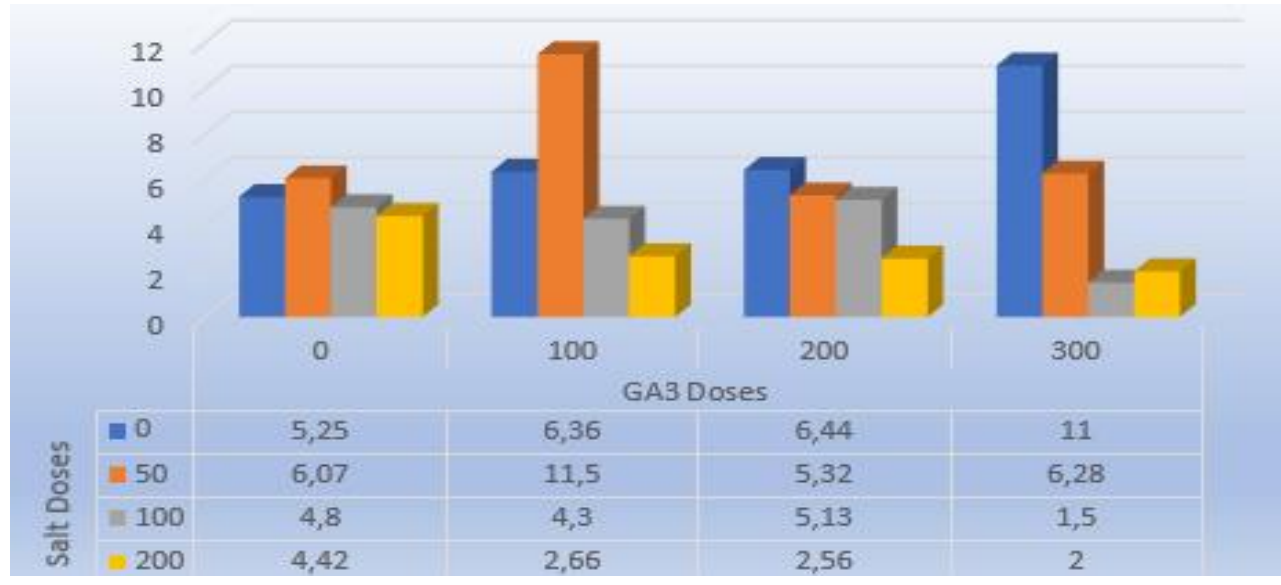

Figure 7. The impact of salt $\times$ GA3 interactions on the plumula length $(\mathrm{cm})$

Table 2. The effect of salt stress on germination characteristics in the Gibberellic acid treated wheat (Triticum durum Desf.) seeds

\begin{tabular}{|c|c|c|c|c|c|c|c|}
\hline \multicolumn{2}{|c|}{ Stress applications } & \multirow{2}{*}{$\begin{array}{c}\text { Radicula } \\
\text { length } \\
\text { (cm) }\end{array}$} & \multirow{2}{*}{$\begin{array}{c}\text { Plumula } \\
\text { length } \\
\text { (cm) }\end{array}$} & \multirow{2}{*}{$\begin{array}{c}\text { Radicula } \\
\text { fresh weight } \\
(\mathrm{mg})\end{array}$} & \multirow{2}{*}{$\begin{array}{c}\text { Plumula } \\
\text { fresh weight } \\
\text { (mg) }\end{array}$} & \multirow{2}{*}{$\begin{array}{c}\text { Radicula } \\
\text { dry weight } \\
\text { (mg) }\end{array}$} & \multirow{2}{*}{$\begin{array}{c}\text { Plumula } \\
\text { dry weight } \\
\text { (mg) }\end{array}$} \\
\hline Salt doses & GA3 & & & & & & \\
\hline \multirow{4}{*}{ Control (T0) } & GA0 & $0.25 \mathrm{e}$ & $5.25 \mathrm{~cd}$ & $32.5 \mathrm{bc}$ & $184.2 \mathrm{c}$ & $3.17 \mathrm{c}$ & $17.7 \mathrm{bc}$ \\
\hline & GA100 & $0.64 \mathrm{de}$ & $6.36 \mathrm{bc}$ & $35.6 \mathrm{~b}$ & $205.6 \mathrm{bc}$ & $3.25 b c$ & $19.3 \mathrm{~b}$ \\
\hline & GA200 & $4.74 \mathrm{~b}$ & $6.44 \mathrm{bc}$ & $34.8 \mathrm{~b}$ & $220.8 \mathrm{~b}$ & $3.22 b c$ & $19.5 \mathrm{~b}$ \\
\hline & GA300 & $11.21 \mathrm{a}$ & $11.00 \mathrm{~b}$ & $42.5 \mathrm{a}$ & $240.5 \mathrm{a}$ & $4.13 \mathrm{a}$ & $25.6 \mathrm{a}$ \\
\hline T0 means & & $4.21 \mathrm{~B}$ & $7.26 \mathrm{~A}$ & $36.3 \mathrm{~A}$ & $213.5 \mathrm{~A}$ & $3.44 \mathrm{~A}$ & $20.5 \mathrm{~A}$ \\
\hline \multirow{4}{*}{$50 \mathrm{mM}$ (T50) } & GA0 & $1.20 \mathrm{de}$ & $6.07 \mathrm{c}$ & $31.2 \mathrm{c}$ & $186.4 \mathrm{~d}$ & $3.08 \mathrm{c}$ & $16.4 \mathrm{~cd}$ \\
\hline & GA100 & $0.19 \mathrm{ef}$ & $11.50 \mathrm{a}$ & $32.5 \mathrm{bc}$ & $189.3 \mathrm{~cd}$ & $3.07 \mathrm{c}$ & $17.2 \mathrm{c}$ \\
\hline & GA200 & $5.64 \mathrm{~b}$ & $5.32 \mathrm{~cd}$ & $29.8 \mathrm{c}$ & $195.4 \mathrm{c}$ & $2.75 \mathrm{~cd}$ & $20.2 \mathrm{~b}$ \\
\hline & GA300 & $10.98 \mathrm{a}$ & $6.28 \mathrm{~h}$ & $24.5 \mathrm{~cd}$ & $196.4 \mathrm{c}$ & $3.55 \mathrm{~b}$ & $22.4 \mathrm{ab}$ \\
\hline T50 means & & $4.50 \mathrm{~A}$ & $7.29 \mathrm{~A}$ & $29.5 \mathrm{~B}$ & $191.8 \mathrm{~B}$ & $3.11 \mathrm{~B}$ & $19.1 \mathrm{~B}$ \\
\hline \multirow{4}{*}{$100 \mathrm{mM}$ (T100) } & GA0 & $4.34 \mathrm{~b}$ & $4.80 \mathrm{~d}$ & $21.5 \mathrm{~d}$ & $132.5 \mathrm{e}$ & $2.03 \mathrm{~d}$ & $12.2 \mathrm{~d}$ \\
\hline & GA100 & $1.77 \mathrm{~d}$ & $4.30 \mathrm{de}$ & $19.8 \mathrm{de}$ & $120.5 \mathrm{ef}$ & $1.86 \mathrm{de}$ & $11.9 \mathrm{de}$ \\
\hline & GA200 & $0.27 \mathrm{e}$ & $5.13 \mathrm{~d}$ & $13.5 \mathrm{e}$ & $95.7 \mathrm{f}$ & $1.23 \mathrm{e}$ & $10.6 \mathrm{e}$ \\
\hline & GA300 & $0.00 \mathrm{f}$ & $1.50 \mathrm{~h}$ & $14.8 \mathrm{ef}$ & $88.6 \mathrm{~g}$ & $1.20 \mathrm{ef}$ & $9.3 \mathrm{ef}$ \\
\hline T100 means & & $1.59 \mathrm{C}$ & $3.93 \mathrm{C}$ & $15.4 \mathrm{C}$ & $109.3 \mathrm{C}$ & $1.63 \mathrm{C}$ & $11.0 \mathrm{C}$ \\
\hline \multirow{4}{*}{$200 \mathrm{mM}$ (T200) } & GA0 & $3.93 \mathrm{c}$ & $4.42 \mathrm{de}$ & $9.8 \mathrm{f}$ & $85.2 \mathrm{~g}$ & $1.15 \mathrm{ef}$ & 9.3 ef \\
\hline & GA100 & $1.87 \mathrm{~d}$ & $2.66 \mathrm{f}$ & $10.8 \mathrm{ef}$ & $65.4 \mathrm{~h}$ & $1.62 \mathrm{e}$ & $6.7 \mathrm{f}$ \\
\hline & GA200 & $0.22 \mathrm{e}$ & $2.56 \mathrm{f}$ & $12.5 \mathrm{e}$ & $65.4 \mathrm{~h}$ & $1.85 \mathrm{de}$ & $6.4 \mathrm{f}$ \\
\hline & GA300 & $0.00 \mathrm{f}$ & 2.001 & $10.5 \mathrm{fg}$ & 71.71 & $0.98 \mathrm{f}$ & $6.0 \mathrm{fg}$ \\
\hline T200 means & & $1.50 \mathrm{D}$ & $2.91 \mathrm{D}$ & $10.9 \mathrm{D}$ & $71.9 \mathrm{D}$ & $1.40 \mathrm{D}$ & $7.1 \mathrm{D}$ \\
\hline \multirow{4}{*}{ Mean GA3 doses } & GA0 & $2.43 \mathrm{~B}$ & $4.86 \mathrm{C}$ & $24.4 \mathrm{~B}$ & $146.3 \mathrm{~A}$ & $2.35 \mathrm{~B}$ & $13.9 \mathrm{C}$ \\
\hline & GA100 & $1.11 \mathrm{C}$ & $6.20 \mathrm{~A}$ & $33.3 \mathrm{~A}$ & $145.2 \mathrm{C}$ & $2.45 \mathrm{~A}$ & $13.8 \mathrm{C}$ \\
\hline & GA200 & $2.71 \mathrm{~B}$ & $5.13 \mathrm{~B}$ & $21.9 \mathrm{D}$ & 144.3 D & $2.31 \mathrm{C}$ & $14.2 \mathrm{~B}$ \\
\hline & GA300 & $5.54 \mathrm{~A}$ & $5.19 \mathrm{~B}$ & $25.1 \mathrm{C}$ & $149.8 \mathrm{~B}$ & $2.46 \mathrm{~A}$ & $15.8 \mathrm{~A}$ \\
\hline CV (\%) & & 8.9 & 13.3 & 12.5 & 15.5 & 13.5 & 11.1 \\
\hline
\end{tabular}

GA0: Control doses, GA100: 100 ppmdoses, GA200: 200 ppm doses, GA300: 300 ppm doses. T0: Control doses, T50: $50 \mathrm{mM}$ salt doses, T100: $100 \mathrm{mM}$ salt doses, T200: $200 \mathrm{mM}$ salt doses

*Difference between the means was evaluated at $\mathrm{P}<0.05$ and $\mathrm{P}<0.01$ level with the Duncan multiple comparison method 
The results obtained from the applications on radicula fresh and dry weights were found to be statistically significant (Table 2; Figs. 8 and 9). The highest radicula fresh and dry weights were observed in the $0 \mathrm{mM}(\mathrm{NaCl})$ application with 36.3 and $3.44 \mathrm{mg}$, respectively. The lowest values $(10.9,1.40 \mathrm{mg})$ were obtained from the $200 \mathrm{mM}$ salt $(\mathrm{NaCl})$ concentration. The effects of Gibberellic acid on the radicula fresh and dry weights were significant, and the highest radicula fresh and dry weights were obtained from the $300 \mathrm{ppm}$ application (25.1 and $2.46 \mathrm{mg}$ ). The lowest values (21.9 and 2.31) were detected in the $0 \mathrm{ppm}$ dose. The salt $\times$ GA3 interactions on the wheat seeds were found to be statistically significant. The highest radicula fresh and dry weights were obtained from the $\mathrm{T}_{0}(0 \mathrm{mM})$ and $300 \mathrm{ppm} \mathrm{GA} 3$ concentration $(42.5$ and $4.13 \mathrm{mg})$, and the lowest radicula fresh weights $(9.8 \mathrm{mg})$ was obtained from $200 \mathrm{mM} \mathrm{NaCl}$ and $0 \mathrm{ppm}$ GA3 doses. The lowest radicula dry weights $(0.98 \mathrm{mg})$ were detected in the $300 \mathrm{ppm}$ GA3 application of the $200 \mathrm{mM}$ salt concentration.

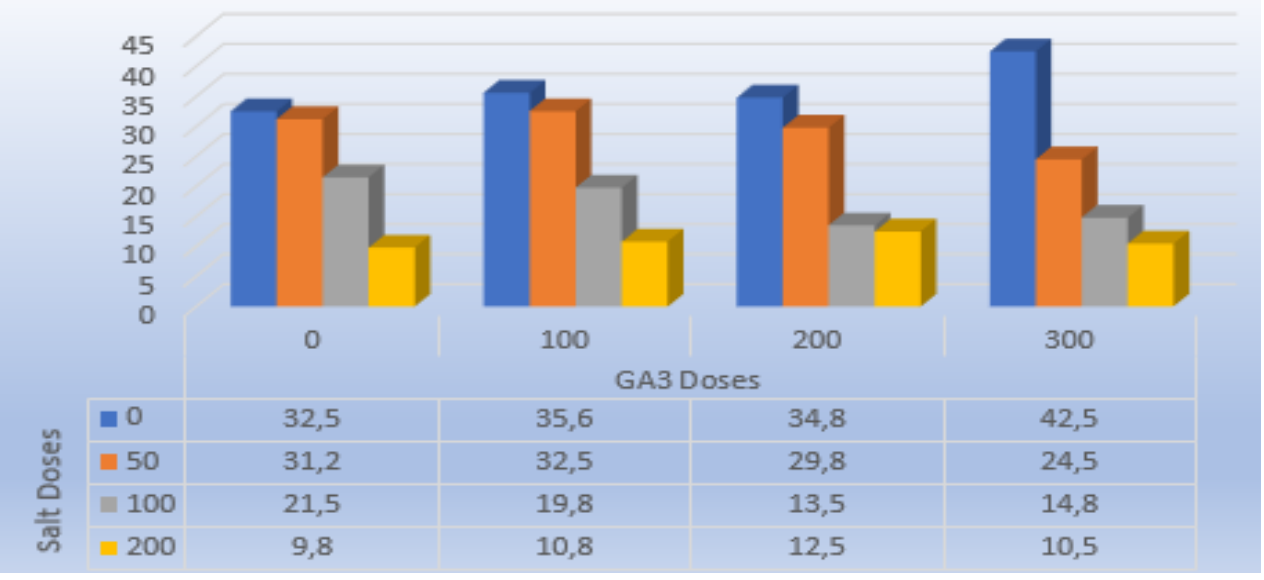

Figure 8. The impact of salt $\times$ GA3 interactions on the radicula fresh weights ( $m g)$

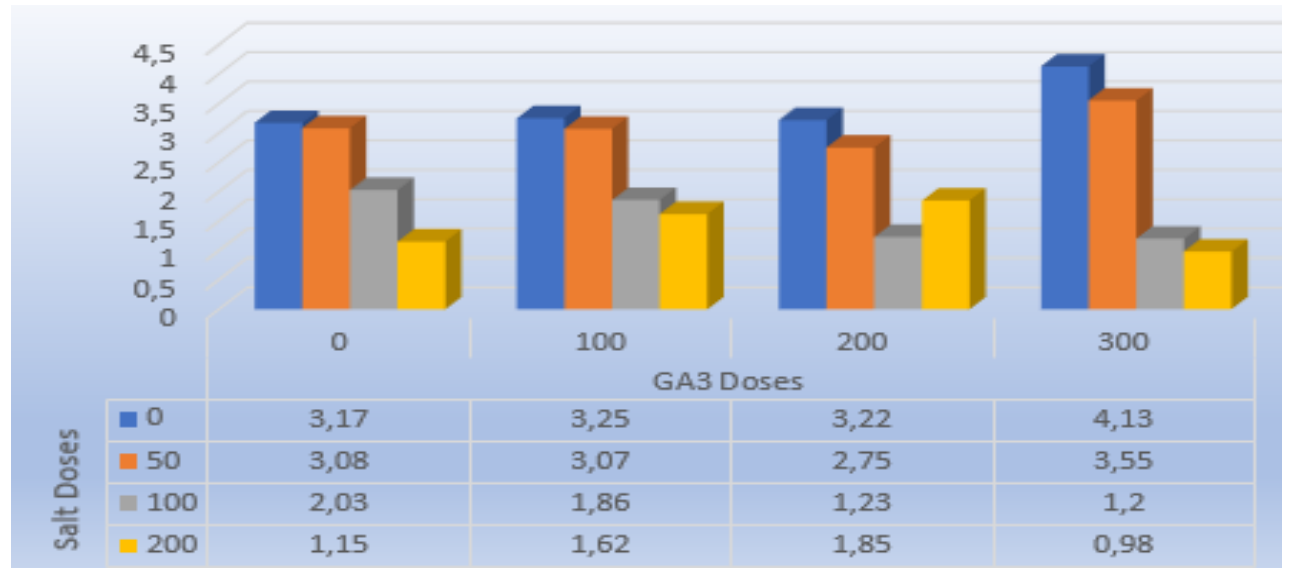

Figure 9. The impact of salt $\times$ GA3 interactions on the radicula dry weights (mg)

The difference between the plumula fresh and dry weights in the applications was found to be statistically significant according to the results (Table 2; Figs. 10 and 11). Considering the results, the results between the plumula fresh and dry weights had parallels regarding the applications. The highest plumula fresh and dry weights were 
found to be 213.5 and $20.5 \mathrm{mg}$, respectively, in the $0 \mathrm{mM}(\mathrm{NaCl})$ application, and the lowest values (71.9 and $7.1 \mathrm{mg}$ ) were obtained from the $200 \mathrm{mM}$ salt $(\mathrm{NaCl})$ concentration. The effects of Gibberellic acid on the plumula fresh and dry weights are significant, and the highest fresh and dry weights (149.8 and $15.8 \mathrm{mg}$ ) were obtained from the $300 \mathrm{ppm}$ application. The lowest values (144.3) were detected in the $200 \mathrm{ppm}$ GA3 doses. The lowest plumula dry weight $(13.8 \mathrm{mg})$ was recorded in the $100 \mathrm{ppm}$ GA3. The salt $\times$ GA3 interactions on the wheat seeds were also found to be statistically significant. The highest plumula fresh and dry weights $(240.5$ and $25.6 \mathrm{mg})$ were obtained from the $\mathrm{T}_{0}(0 \mathrm{mM})$ and $300 \mathrm{ppm}$ GA3 concentration, and the lowest plumula fresh weight values (65.4) was detected in the $200 \mathrm{ppm}$ GA3 concentration of the $200 \mathrm{mM}$ salt concentration. The lowest plumula dry weight $(6.0 \mathrm{mg})$ was detected in the 300 ppm GA3 concentration of the $200 \mathrm{mM}$ salt concentration

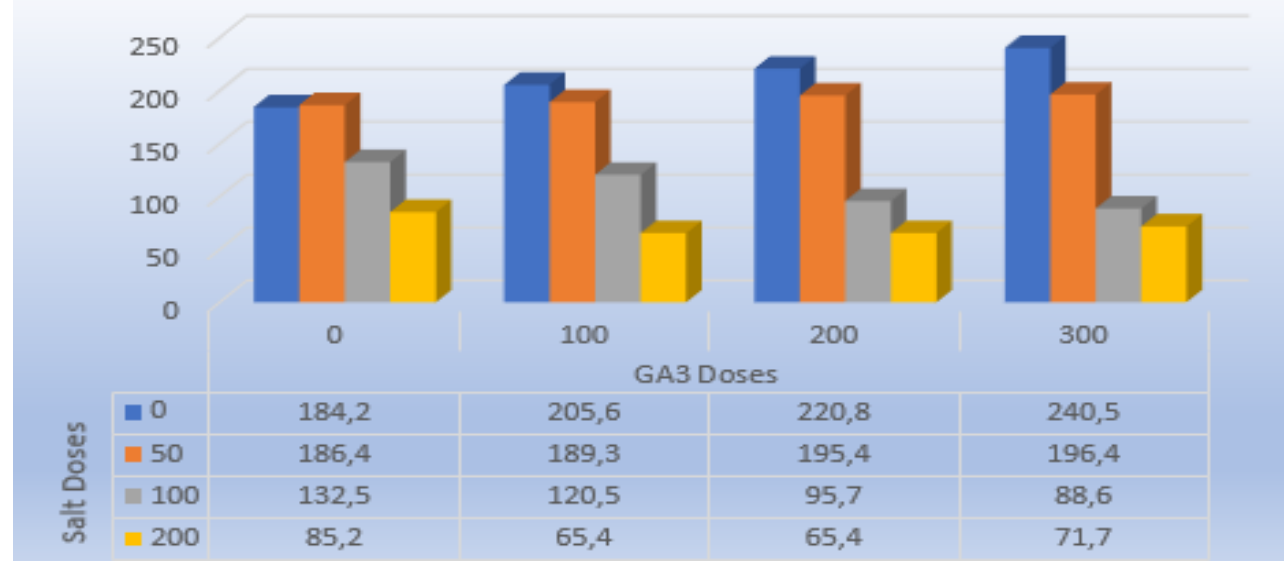

Figure 10. The impact of salt $\times$ GA3 interactions on the plumula fresh weights $(\mathrm{mg})$

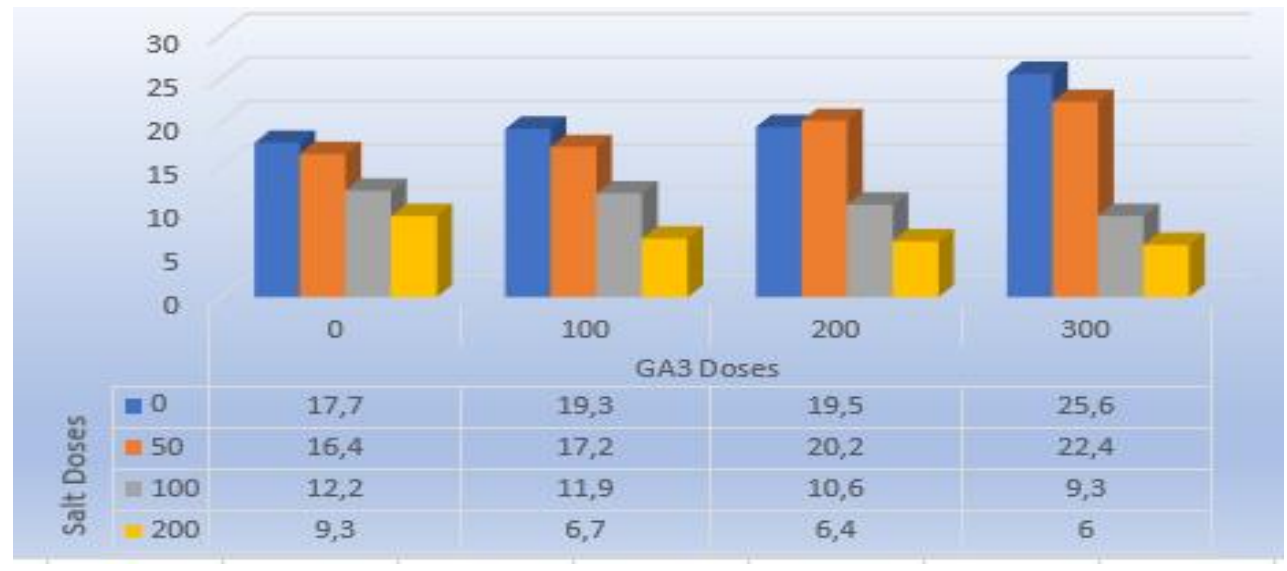

Figure 11. The impact of salt $\times$ GA3 interactions on the radicula dry weights $(\mathrm{mg})$

\section{Discussion}

The results indicated that the GA3 applications caused the germination power and the germination ratio to increase. However, in the similar studies, it was stated that the increasing salt concentrations had negative and important effects on these ratios (Sharma et al., 2004; Khan et al., 2005; K1zılgeci et al., 2010). 
According to the results, growth and development of the wheat seeds were prevented due to the salinity concentration, which increased gradually. Many researchers had revealed this effect before (Öztürk et al., 1994; Gulzar and Khan, 2002; Y1ldız et al., 2017).

When the GA3 pretreatments on the wheat seeds are examined, mean germination days decreased in parallel with the increasing doses, and it was observed in similar studies that this time lengthened together with the increasing doses in salt concentrations (Öztürk et al., 1994; Ghoulam and Fores, 2001; Gulzar and Khan, 2002; Çavuşoğlu et al., 2007).

In their studies, Yuonesi and Moradi (2015) stated that the gibberellic acid applications had positive and significant effects on germination index despite the increasing salt doses.

It was observed that the gibberellic acid pretreatments were useful regarding the sensitivity index values as in the other parameters (Yuonesi and Moradi, 2015).

As significant decreases in the water intake capabilities occur in the plants that are under salt stress, root and shoot lengths decrease (Kızılgeçi and Yıldırım, 2014). While radicula length is important from this point of view, it should be considered as a selection criterion in salt resistance improvement. According to the results, radicula length decreased depending on the increasing salt concentration (Atak et al., 2006; Saboora and Kriarostami, 2006).

The highest stem length $(6.20 \mathrm{~cm})$ was obtained from the GA100 dose, and the lowest was $4.86 \mathrm{~cm}\left(\mathrm{GA}_{0}\right)$. In the salt $\times \mathrm{GA} 3$ interaction, the highest plumula length $(11.50 \mathrm{~cm})$ was obtained from the $\mathrm{T}_{50} \times \mathrm{GA}_{100}$ application, and the lowest value was observed to be $1.50 \mathrm{~cm}\left(\mathrm{~T}_{100} \times \mathrm{GA}_{300}\right)$. Sadat Noori and McNeilly (2011) found similar results.

It was observed that increasing salt concentrations reduced the radicula fresh and dry weights (Kızılgeçi and Yı1dırım, 2014).

According to the results obtained in our research, it was observed that the GA3 applications increased radicula fresh and dry weights relatively. In a study they conducted with local bread wheat varieties, Shahzad et al. (2012) detected that radicula fresh and dry weights decreased. It was stated that this parameter could be used in improvement works.

It was observed that increasing salt concentrations reduced the plumula fresh and dry weights (Kızılgeçi and Yıldırım, 2014).

In similar studies, it was stated that increasing salt concentrations reduced plumula fresh and dry weights in plants (Muhammad and Hussain, 2012; Akbari et al., 2007).

\section{Conclusion}

According to the results, germination and growth of wheat seeds were prevented depending on the gradually increasing salinity concentration. Many researchers had revealed this effect before. It prevents water intake especially in high salt concentrations, and based on this, it causes the enzymes to not to be able to activate and in consequence leads to retardation in germination and growth. In this study, this negative and important effect of salt on the germination parameters was reduced as a result of GA3 applications and successful results were obtained. When the results were evaluated in terms of all the parameters, the best results were obtained from the 300 ppm GA3 applications in $0 \mathrm{mM}$ salt concentration. In conclusion, it was observed that 
GA3 (Gibberellic acid) pretreatments lessened the effect of salt $(\mathrm{NaCl})$ stress on germination in wheat seeds. In the world and in our country, as well as fallow fields, soil salinity and alkalics are an important problem. It will be possible to bring these areas to agriculture and increase agricultural production only through these and similar studies.

\section{REFERENCES}

[1] Anonymous (2015): www.agri.ankara.edu.tr/fcrops/1289_B1tkılerde_Stres.pdf. - Access date: 15.05.2015 (in Turkish).

[2] Akbari, G., Sanavy, S., Yousafzadeh, S. (2007): Effect of auxin and salt stress ( $\mathrm{NaCl})$ on seed germination of wheat cultivars (Triticum aestivum L). - Pak. J. Biol. Sci. 10(15): 2557-2561.

[3] Akınc1, I. E., Calıskan, U. (2010): Effect of lead on seed germination and tolerance levels in some summer vegetables. - Ekoloji Dergisi 19: 164-172 (in Turkish).

[4] Atak, M., Kaya, M. D., Kaya, G., K1llı, Y., Ciftci, C. Y. (2006): Effects of $\mathrm{NaCl}$ on the germination, seedling growth and water uptake of Triticale. - Turkish J. Agric. Forestry 30: 39-47.

[5] Azizi, M., Chehrazi, M., Zahedi, S. M. (2011): Effects of salinity stress on germination and early growth of sweet william (Dianthus barbatus L.). - Asian Journal of Agricultural Sciences 3(6): 453-458.

[6] Begum, F., Karmoker, J. L., Fattah, Q. A., Maniruzzaman, A. F. M. (1992): The effect of salinity and Its correlation with $\mathrm{K}+, \mathrm{Na}+, \mathrm{Cl}$ accumulation in germinating seeds of Triticum aestivum L. cv. - Akbar. Plant Cell Phsysiol 33(7): 1009-1114.

[7] Çavuşoğlu, K., Kılıç, S., Kabar, K. (2007): Some morphological and anatomical observations in alleviating salt stress with gibberellic acid, kinetin and ethylene during germination of barley seeds. - Sdü Fen Edebiyat Fakültesi Fen Dergisi (E-Journal) 2(1): 27-40 (in Turkish).

[8] De Villiers, A. J., Van Rooyen, M. W., Theron, G. K., Van De Venter, H. A. (1994): Germination of three Namaqualand pioneer species, as influenced by salinity, temperature and light. - Seed Sci. Technol. 22: 427-433.

[9] Dölarslan, M., Gül, E. (2012): Soil salinity in terms of plant relations. - Türk Bilimsel Derlemeler Dergisi 5(2): 56-59 (in Turkish).

[10] Duman, İ., Eşiyok, D. (1998): Effects of PEG and KH2PO4 applications before germination on germination rate and yield of carrot seeds. - Tr. J. of Agriculture and Forestry 22: 445-449 (in Turkish).

[11] Duzgunes, O., Kesici, T., Kavuncu, O., Gurbuz, F. (1987): Research and experimental methods. Statistical methods-II. - Ankara University, Agr Fac Press 1021: 295 (in Turkish).

[12] Ellis, R. H., Roberts, E. H. (1980): Towards a Rational Basis for Testing Seed Quality. In: Hebblethwaite, P. D. (ed.) Seed Production. Butterworths, London, pp. 605-63.

[13] Ercişli, S., Eşitken, A., Güleryüz, M. (1999): The effect of vitamines on the seed germination of apricots. - Acta Hort. 488: 437-440.

[14] Flowers, T. J., Yeo, A. R. (1981): Variability in the resistance of sodium chloride salinity within rice (Oryza sativa L.) varieties. - New Phytology 88: 363-373.

[15] Foolad, M. R., Lin, G. Y. (1997): Genetic potential for salt tolerance during germination in Lycopersicon species. - HortScience 32: 296-300.

[16] Gupta, S. C., Srivastava, J. P. (1989): Effect of salt stress on morpho-physiological parameters in wheat. - Indian J. Plant Physiol. 32(2): 169-171.

[17] Ghoulam, C., Fores, K. (2001): Effect of salinity on seed germination and early seedling growth of sugar beet (Beta vulgaris L.). - Seed Science Technology 29: 357-364. 
[18] Gulzar, S., Khan, M. (2002): Alleviation of salinity-induced dormancy in perennial grasses. - Biologia Plantarum 45(4): 617-619.

[19] Hartmann, H. T., Kester, D. E., Davies, F. T. (1990): Plant Propagation. Principles of Propagation by Seed. - Prentice Hall, Upper Saddle River, NJ.

[20] Hasegawa, P. M., Bressan, R. A., Handa, A. V.(1986): Cellular mechanism of salinity tolerance. - Horticultural Science 21(6): 1317-1324.

[21] İnal, A., Güneş, A., Aktaş, M. (1995): Effects of chloride and partial substitution of reduced forms of nitrogen for nitrate in nutrient solution of the nitrate, total nitrogen and chlorine contents of onion. - Journal of Plant Nutrition 18: 2219-2227.

[22] ISTA (1996): International Rules for Seed Testing. Edition 1996/6. - International Seed Testing Association, Zurich.

[23] Khan B. A., Khan, A. N., Khan, T. H. (2005): Effect of salinity on the germination of fourteen wheat cultivars. - Gomal University Journal of Research 21: 31-33.

[24] Khan, M. A., Ungar, I. A. (1997): Effects of light, salinity and thermoperiod on the seed germination of halophytes. - Can. J. Bot. 75: 835-541.

[25] Kızılgeçi, F., Yıldırım, M., Akinci, C. (2010): Determination of salinity responses of some bread wheat genotypes. - 1. Uluslararası Kat1lımlı Kamu-Üniversite-Sanayi işbirliği Sempozyumu ve ermercilik şuras1, 24-26 May 2010, Diyarbakır, Turkey, pp. 301-307 (in Turkish).

[26] Leopold, A. C., Willing, R. P. (1984): Evidence of Toxicity Effects of Salt on Membranes. - In: Staples, R. C., Toenniessen, G. H. (eds.) Salinity Tolerance in Plants. Wiley, New York, pp. 67-76.

[27] Muhammad, Z., Hussain, F. (2012): Effect of $\mathrm{NaCl}$ salinity on the germination and seedling growth of seven wheat genotypes. - Pak. J. Bot. 44(6): 1845-1850.

[28] Özkald1, A., Boz, B., Yazıc1, V. (2004): Drainage problems and solutions in GAP. Sulanan Alanlarda Tuzluluk Yönetimi Sempozyumu, 20-21 May, Ankara, pp: 97-105.

[29] Öztürk, M., Gemici, M., Özdemir, F., Keyikçi, N. (1994): The role of plant hormones and germination simulator in reducing salt stress in seed germination. - XII. Ulusal Biyoloji Kongresi, Edirne, pp. 44-48.

[30] Parida, A. K., Das, A. B. (2005): Salt tolerance and salinity effects on plants: a review. Ecotoxicol. Environ. Saf. 60: 324-349.

[31] Pessarakli, M., Tucker, T. C., Nakabayashi, K. (1991): Growth response of barley and wheat to salt stress. - Journal of Plant Nutrition 14(4): 331-340.

[32] Saboora, A., Kriarostami, K. (2006): Salinity ( $\mathrm{NaCl})$ tolerance of wheat genotypes at germination and early seedling growth. - Pakistan J. of Bio. Sci. 9(11): 2009-2021.

[33] Sadat Noori, S. A., McNeilly, T. (2000): Assessment of variability in salt tolerance based on seedling growth Triticum durum Desf. - Genetic Resources and Crop Evolution 47: 285-291.

[34] Sariye, U. K. (2014): Tolerance of salt of some lentil (Lens culinaris Medic.) Varieties during germination and seedling period. - Diss. Selçuk Üniversitesi Fen Bilimleri Enst., Konya (in Turkish).

[35] Shahzad, A., Ahmad, M., Iqbal, M., Ahmed, I., Ali, G. M. (2012): Evaluation of wheat landrace genotypes for salinity tolerance at vegetative stage by using morphological and molecular markers. - Genet. Mol. Res. 11(1): 679-692.

[36] Shannon, M. C. (1984): Breeding Selection and the Genetics of Salt Tolerance. Salinity Tolerance in Plant Strategies for Crop Improvement. - Wiley-Interscience, New York, 231-254.

[37] Shannon, M. C. (1985): Principles and strategies in breeding for higher salt tolerance. Plant and Soil 89: 227-241.

[38] Sharma, A. D., Thakur, M., Rana, M., Singh, K. (2004): Effect of plant growth hormones and abiotic stresses on germination, growth and phosphoaphatse activities in Sorghum bicolour (L.) moench seeds. - Afr. J. Biotechnol. 3: 308-312. 
[39] Şenay, A., Kaya, M. D., Atak, M., Çiftçi, C. Y. (2005): Effects of different salt concentrations on germination and seedling growth of some bread wheat varieties. - Tarla Bitkileri Merkez Araştırma Enstitüsü Dergisi 14(1-2): 50-55.

[40] Siegel, S. M., Siegel, B. Z., Massey, J., Lahne, P., Chen, J. (1980): Growth of corn in saline water. - Physiology Plant 50: 71-73.

[41] Taghipour, F., Salehi, M. (2008): The study of salt tolerance of Iranian barley (Hordeum vulgare L.) genotypes in seedling growth stages. - American-Eurasian J Agric. \& Environ. Sci. 4(5): 525-529.

[42] Van Hoorn, J. W. (1991): Development of soil salinity during germination and early seedling growth and its effect on several crops. - Agricultural Water Management 20: 1728.

[43] Van Hoorn, J. W., Katerji, N., Hamdy, A., Mastrorilli, M. (2001): Effect of salinity on yield and nitrogen uptake of four grain legumes and on biological nitrogen contribution from the soil. - Agricultural Water Management 51: 87-98.

[44] Wang, Y. R., Yu, L., Nan, Z. B., Liu, Y. L. (2004): Vigor tests used to rank seed lot quality and predict field emergence in four forage species. - Crop Sci. 44(2): 535-541.

[45] Younesi, O., Moradi, A. (2015): Effect of different priming methods on germination and seedling establishment of two medicinal plants under salt stress conditions. - Cercetari Agronomice în Moldova 48(3): 43-51.

[46] Yıldız, M., Kasap, E., Konuk, M. (2007): Salinity, temperature and effects of light on seed germination. - Afyon Kocatepe Üni. Fen Bilimleri Dergisi 7(1): 225-243 (in Turkish).

[47] Yıldız, S., Karagöz, F. P., Dursun, A. (2017): Germination of Hüsnüyusuf (Dianthus barbatus L.) seeds subjected to gibberellic acid pretreatment in salt stress. - Atatürk Üniv. Ziraat Fak. Derg. 48(1): 1-7 (in Turkish).

[48] Y1lmaz, E., Tuna, M., Bürün, B. (2011): Tolerance strategies developed by plants against salt stress effects. - C. B. Ü. Fen Bilimleri Dergisi 7(1): 47-66 (in Turkish).

[49] Zheng, C., Jiang, D., Liu, F., Dai, T., Liu, W., Jing, Q., Cao, W. (2009): Exogenous nitric oxide improves seed germination in wheat against mitochondrial oxidative damage induced by high salinity. - Environ. Exp. Bot. 67: 222-227. 